\title{
The Procrustean Bed of Colonial Laws: A Case of the British Empire in India
}

\author{
Parvathi Menon"
}

"The goddess of British Justice, though blind, is able to distinguish unmistakably black from white"-Bal Gangadhar Tilak, 1907

\section{Introduction}

The Anglicization of law in the British Empire was primarily based on the perceived primitiveness of the native laws and the superiority of the modern British legal system. Maintaining the South Asian 'identity' of the law, while distancing the law from the community it belonged to, the British used procedural mechanisms to tilt the jurisprudence towards the Anglo direction. Procedural justice is often considered as the last bastion of a means to just and equitable practices; this paper hopes to expose the dark sides of the procedural mechanisms that succeeded in helping the British gain control over the Indian polity, through a contrast of the pre-colonial legal systems of India against the British legal interventions.

Historical accounts of post-colonial legal systems suffer from, what Dipesh Chakrabarty calls, the "first in Europe, then elsewhere" structure of historical time, ${ }^{1}$ ignoring in entirety the pre-colonial identity of the subaltern. Such historicist arguments lead to a characterization that Indians were not yet civilized to govern themselves. To overcome these characterizations, the possibilities are twofold: first, to demonstrate how the natives were not in fact uncivilized as the colonial powers claimed, thus delegitimizing the colonial attempts to civilize; second, to demonstrate how the attempts to civilize were in fact a means to subordinate the natives, rendering inconclusive the narrative that portrays a "practical European" nature against a "mythical-religious Orient". ${ }^{2}$ The exploration of these two possi-

* Research Fellow at the Max Planck Institute Luxembourg for Procedural Law.

1 D. Chakrabarty, Provincialising Europe: Postcolonial Thought and Historical Difference (2008).

2 Ibid., page 29 et seq. 
bilities in the context of the British efforts to anglicize the laws form the foundation upon which this chapter will discuss the judicial mechanisms implemented in India, leading to the two axes to my work.

In the first part, I am seeking first of all to examine the legal mechanisms from within the pre-colonial Indian context: this will help particularize the paper against the universal narrative of procedural guarantees. The section will address why the notion surrounding the primitiveness of the Indian laws had no real foundational basis; in so doing, I will examine the prevalent pre-colonial systems in India to show how, albeit different from the British, the Hindu and Mohammedan methods of justice had their own internal logic and method that best suited the cultural context in a diverse polity like India. Without comparing it to the European model introduced by the British, the first part will enunciate the core characteristics of the pre-colonial systems that helped sustain the communities that relied on them, thus providing an unfamiliar portrayal of a diverse, but ordered pre-colonial society of India.

In the second part, I examine the strategies used by the British and the benefits accrued to them by transplanting their laws into India and unifying the laws between the two religious communities. The methods of codification and translation were used to create a pall of 'bridging the gap', whilst in reality broadening it. The rationale was slated to be an effort to modernize through a uniform code that abandoned the traditional and primitive Indian system, while in reality institutionalizing inequalities that favoured the British. In bringing about the said uniformity, removing the relevance of the social background of persons appealing to the law for justice - the universalized approach — provided the foundation for what today is called "(un)equal treatment before the law". Through an examination of the new legal technologies introduced, I demonstrate the ramifications of the changes made to the legal system from the $16^{\text {th }}$ century to the $19^{\text {th }}$; this shall show how the British laws were used to curb the interpretative process that was considered integral to the Hindu and Islamic law in the precolonial context. Furthermore, this part will demonstrate that the introduction of the British procedures and efforts to codify were based on the colonial effort to create a society that was governable by the British. This required that laws were more uniform and also familiar to the colonial powers, whilst equally capable of creating privileges and exemptions for the white race against the natives. Thus, what seemed like a propagation of equality and fairness through the British procedural rules was, I argue, a veneer for the inequality they perpetuated through extremely legal means.

The mythological Procrustean Bed-depicting the illusion that there must be a "right sized" human being who fits the bed, in the absence of 
which the person must be stretched or cut-short in order to be suitable-is the perfect metaphor to highlight the approach of the 'fitting' procedures implemented by the British Empire. This paper, in describing the various attempts of the British to 'stretch' or 'cut-short' the laws, argues against their supposition that substantive differences could be tackled with procedural uniformity.

\section{The Primitiveness of the Other?: A Study of the Pre-Colonial Indian Legal Systems}

The classifications of modern and primitive or civilized and uncivilized were typically a means used by the British Empire in order to justify their methods in bringing about 'order' amongst the uncivilized populations. Legal transplants were one such method; they allude to the removal and consequent repositioning of legal systems from one jurisdiction to another. The British attempt at transplanting their rules and procedures to the Indian subcontinent was, as most legal transplants are stated to be, to bring about the 'modern' legal system in place of the 'primitive' Indian one. ${ }^{3}$

Dismissing the Indian pre-British law as primitive, scholars like Marc Galanter describe the lack of written records, professional staff, and a hierarchy of courts organized bureaucratically and employing 'rational' procedures as the reasons. ${ }^{4}$ James Stephen, who served as an Indian Law Commissioner from 1870 to 1879 , described the pre-British Indian legal system as governed by the whims and fancies of its rulers and the village communities. ${ }^{5}$ James Mill, in his utilitarian manner, remarked that in order to create a society where one's individual rights and freedoms can be protected and where competitiveness can be fostered, the traditional Indian legal system needed to disappear. ${ }^{6}$ Lord Macaulay, the British Member of Parlia-

3 M. Galanter, The Displacement of Traditional Law in Modern India, 24(4) Journal of Social Issues (1968).

4 Ibid. Cf., D. Suky, Macaulay and the Indian Penal Code of 1862: The Myth of the Inherent Superiority and Modernity of the English Legal System Compared to India's Legal System in the Nineteenth Century, 32(3) Modern Asian Studies (1998), 513-557.

5 During his tenure, James Stephen was responsible for passing numerous codesthe Indian Limitation Act, 1871, a revised Criminal Procedure Code, 1872, and the Indian Contract Act, 1872. See K. J. M. Smith, James Fitzjames Stephen: Portrait of a Victorian Rationalist (1988).

6 See E. Stokes, The English Utilitarians and India (1959). It is interesting to note here that it was not only the Western scholars who deemed the Indian system as 
ment who served on the Indian Supreme Court between 1834 and 1838, was renowned for his attempts at unifying the Indian laws through a transplant of British laws. The large part of their claims resided in the diversity of the Indian cultural context, leading to what they claimed was a dysfunctional and fragmented system in desperate need of uniformity. Though little research has been carried out to provide a clear picture of the Indian legal systems prior to the arrival of the British, historians are always quick to characterize the Indian law as primitive. Rarely did scholars suggest that the Indian legal systems were worth preserving. The following sections will demonstrate that both, the Hindu and Mohammadan systems had their own practices which followed an internal logic that was unlike the Western ideas about justice, in order to particularize the universal notions surrounding judicial methods and practices.

\section{A. Hindu Law and Its Practices}

The Hindu system characterized the stages of legal problems and solutions based on whether they were generated by doubt or brought about by a dispute. The former proceeded through a consultative process while the latter was put through the more formal court processes. Legal doubt (or samedha) could accompany or precede a legal dispute (or virodha), but it could equally be resolved without the complainant enduring the formal legal process. Therefore, a legal problem was characterized as either a dilemma/ doubt or a conflict/dispute; thereafter it was expressed as a question/ inquiry/request (prasna/prarthana/paripracha) or a formal plaint (bhasal artha/pratijna) respectively; the final step was that of the legal responses and they ranged from an opinion/response to a verdict, depending on the formulation of the problem.

primitive, but there were prominent Indian scholars like B. N Pandey and Motilal Setalvad (a former Chief Justice of India), who endorsed such view. The criticisms that Hindu law, for example, was based on superstitions and arbitrary religious beliefs found support amongst the natives themselves. See B. N. Pandey, The Introduction of English Law into India: The Career of Elijah Impey in Bengal 1774-1783 (1967), 19-25; M. Setalvad, The Common Law in India (1960). 


\section{Legal Consultations}

Studies show that the consultative processes were more common than the formal trials because the former, which involved consulting with a learned Brahmin (member of the priestly class) or Brahmin council, was quicker, less expensive and offered a more accessible alternative to formal court processes in medieval India. The histories of such consultations in Hindu law are devoid of much evidence owing to the oral nature of the processes. However, as Donald Davis enunciates in his wide research on the concept of the practice of legal consultations in Hindu legal systems, ${ }^{7}$ there nonetheless were pieces of evidence that allowed a sketching of its history. While the credit for the consultative process, that he calls responsas, is often attributed to the British, it was very much in existence prior to their rule. He describes the evidence of this to be present in material dating back to $1500 \mathrm{AD}$, in the narration of legal consultative practices found in the epic pieces of literature of Mahabharata and Ramayana and in the dharmasastra (which according to Davis contains, in clearly stipulated terms, evidence of legal consultation as a pivotal mechanism for the functioning of Hindu law).

Albeit legal consultations have the veneer of an informal practice, in the context of many older legal systems (whether Roman, Canon, Jewish or Islamic), practices of 'responsum' provided an important source of law. ${ }^{8}$ The abstract nature of these legal consultations formed the basis of their characterization as an informal mechanism. The investigations surrounding the dispute were carried out by the religious leaders keeping in mind more of an abstract depiction of the facts, without indulging in the specificities. This was done mainly to allow the responsas to provide a future use, much like the concept of precedents; ${ }^{9}$ but given they were mainly unwritten, responsas rarely provided the precedential value intended. Through the legal consultations, there was a distinctiveness created from judicial proceedings, although certain Hindu texts on the legal procedure (e.g. nirnaya, vyavastha and parisad) are said to be better comprehensible in a combined

7 D. R. Davis, Responsa in Hindu Law: Consultation and Lawmaking in Medieval India, 3 Oxford Journal of Law and Religion (2014), 57-75.

8 Ibid., 59-60.

9 This, as I shall demonstrate in the later sections, was in contrast with how the Islamic jurisprudence was created; there was little room for precedents, with more room for specificities. One of the main reasons for the British to inculcate the use of precedents was in order to rid the legal system of its reliance on the religious leaders who were required for the interpretation of the law for each matter. 
study of both, the consultative processes and formal judicial procedures. Whilst the tradition of the consultative process was not limited to the Hindus, when the responders were Brahmins or other Hindu sectarian leaders, their determinations possessed a religious character that could be classified as Hindu, molded by the tradition of the Dharmasastra. Thus procedurally, the consultative processes did not rely on the formalities entailed in a court process, and focused more on simpler means to finding solutions. The procedures stressed on the morality of the religious leaders, who the scriptures did not deem outside the realm of its control. While the class structure of the society provided many concessions to the Brahmins (for e.g. fiscal immunities were granted to them for providing their religious merit), they were subjected to punishments much like the common man, if found in violation of the religious codes. The rights and duties of the Brahmins are outlined in the Manusmriti, which in turn relied on the Vedas. ${ }^{10}$

\section{Formal Court Processes}

Apart from legal consultations, formal trials were as much an integral part of the Hindu legal system. Depicting a hierarchical structure, contrary to Galanter's assertions, the Brihaspati Smriti (from the Dharmasastras) is evidence of how the King was at the apex, followed by the Chief Justice (also called Praadivivaka, or Adbyaksha), with the family courts at the lower end of the hierarchy. Within the family courts, the family arbitrator was considered to be at the bottom of the order. ${ }^{11}$

The court processes, unlike consultations, were rife with rules that governed its various aspects, both substantive and procedural. In the case of criminal law, the Manusmriti ${ }^{12}$ (from the Dharmasastras) details the rules that govern litigation, classifying crimes into eighteen different titles (or vyavahara-padas) in an ordered and systematic manner to which subsequent authors of smritis and other interpreters adhered. Given the king was at the helm of conducting the trial, there was a requirement under the $M a$ -

10 Vedas are a collection of ancient hymns and religious texts that provide the wisdom underlining the philosophy of Hinduism.

11 R. Lingat, The Classical Law of India (translation from the French by Duncan M. Derrett) (1973).

12 The Laws of Manu (translation from Sanskrit by Georg Buhler) (1886). The Manusmriti is an extensive document that spells out the laws for the Brahmin (priestly class) and the Kshatriyas (the administrative and warrior class), listing recommended virtues that different classes must possess. 
nusmriti to provide at his disposal a means of enquiry and investigation. The justifications for the punishments for different crimes were based on strategies of retribution or prevention which, although scholars like Robert Lingat call arbitrary, are not different from the strategies behind the goals of punishments today. ${ }^{13}$

Procedurally, though the Manusmriti gives the morality of the judge more importance than to the demonstration of the trial, rules of a juridical character were often found mixed with moral exhortations. ${ }^{14}$ Not all aspects of procedure as we know today were covered by the sacred texts, but certain aspects received an elaborate description: for example, the rules of procedure governing means of proof. The Gautama Sutra (from the Dharmasastra) dedicates an entire chapter (XIII) to the procedure for gathering evidence from witnesses, including their conduct and the consequences of giving false evidence. ${ }^{15}$ Another aspect of the Hindu law practices that finds much mention in scholarly texts is of its extensive reliance on facts. The routes of legal procedure find explicit mention in one of the texts of the Dharmasastra, the Laws of Yajnavalkya. As Mitakshara's commentary on the text describes:

Just as a plaintiff and a defendant speak only the truth, so also must the ruler of the court and his judges be controlled by employing the standard techniques of friendly speech, etc. When this is the case, the decision can be made without considering witnesses or other means of proof (i.e., the facts are mutually stipulated). But precise ascertainment of the facts is not possible in every case. When it is not, a decision must be reached utilizing witnesses as an acceptable alternative. A legal procedure that follows the facts is the principal, and one that follows legal maneuvers is the alternative. In deciding a legal procedure using witnesses, documents, etc. sometimes a precise ascertainment of the facts is possible and sometimes not, because of the deviations and manipulations of witnesses, and so on.

13 For an overview of the manifestations of the traditional goals of criminal justice (retribution, rehabilitation and deterrence) in the jurisprudence of international criminal law today, see A. Heinze, International Criminal Procedure and Disclosure (2014), page 211 et seq.

14 For example, law no. 14, Chapter VIII, The Laws of Manu (translation from Sanskrit by Georg Buhler) (1886) which read: "Where justice is destroyed by injustice, while the judges look on, there they shall also be destroyed."

See also Lingat, supra note 11, page 93.

15 Gautama Sutra (1897) (translated by Georg Bühler), Chapter XIII. 
The importance given to facts can also be found in relation to the psychosocial facts of the judges, the witnesses and the litigants. In modern jurisprudence, the political leanings of the judges are often considered a barrier to their independence. ${ }^{16}$ In Hindu law scholarship, on the contrary, their psychological profiles, their social preferences, along with their education and the disciplines of their training were all considered insightful towards reducing the arbitrariness and unpredictability of the law they were interpreting. Such an advanced approach to the understanding of law and its readability was not common in most 'civilized' legal systems, even if based on a simple appeal to reason, logic and common sense (yukti, nyaya, etc.). The general approach of Hindu law had been to take into account the surrounding circumstances and motivations to a case while making judicial decisions. Therefore terms like "equity and good conscience" which became preponderant in the post-colonial legal terminologies of the Indian legal system, can be traced back to the Hindu law system, even if credit is often given to the British. I do not cite these examples simply to show a hangover of the Hindu system or as praise of a pre-modern sense of virtue. They merely serve as pushback against the narrative of a stark transition from primitive to modern, as claimed by the British.

From the above descriptions of Hindu legal practices, it can be gathered that there were trends that were considered 'primitive' by the British during their reign, despite such practices sometimes resonating with Western judicial practices. Whether the informal nature of legal consultations or the reliance on religious customs, Hindu law practices were replete with what today can be called progressive means of thinking about the law and its application. There were aspects of the sastric system of justice that were criticized by historians, like the role of the ruler, the supposed lack of independence or impartiality of the judges, that litigants could not move a formal court without a prior petition to the ruler, etc. ${ }^{17}$ This, as was described by the critics of modern Hindu law, ${ }^{18}$ was the basis for the preference given to the uniform state statute law which met the constitutional and progressive standards ${ }^{19}$ of the British. This does not lead to the natural conclusion

16 For a critical take on the adjudicative process that constantly attempts to portray a depoliticized view of the judges and the legal system, see Duncan Kennedy, The Critique of Adjudication: Fin de Siecle (1997).

17 G. Smith and J. D. M. Derrett, Hindu Judicial Administration in Pre-British Times and Its Lesson for Today, 95 Journal of the American Oriental Society (1975).

18 See J. D. M. Derrett, Critique of Modern Hindu Law (1970).

19 Smith and Derrett, supra note 17, 421. 
of the British system being superior. On the contrary, unlike what the British brought about through their sets of definitions and rigid approaches to law, the Hindu law, through the Dharmasastra, exemplified openness through its rejection of formalism and an awareness of the indeterminacy of law, ${ }^{20}$ the importance given to facts in adjudication, ${ }^{21}$ and an approach that prided itself on its practicality. ${ }^{22}$ Its context-driven approach with respect to different legal procedures exemplified a thinking that showcased its advantages; for example, as stated above, there were no automatic punishments for particular crimes. "The dharmasastras did not hold that the same punishment must be meted out for the same offence irrespective of the antecedents, characteristics or physical and mental condition of the offender. They always took extenuating circumstances into account." ${ }^{23}$ This was in stark contrast to the Indian Penal Code and the Criminal Procedure Code that the British created for the Indians, in replacing the Hindu (and Islamic) laws. Thus whether it was, in fact, Hindu law that could be described as 'primitive law', through a comparison with the British measures and concept of justice, is moot.

\section{B. Mohammadan Law and Its Practices}

Much like the relationship between the British and the Hindu legal system, the concept of law differed widely between the British and the Muslims as well. The Sharia was the accepted custom of the Muslim community in pre-British India, whether in terms of their doctrinal belief, ritual actions, commercial dealings or criminal punishment. ${ }^{24}$ During the rule of the Delhi sultanates and the Mughals in Medieval India, the application of Sharia law gave the rulers legitimacy, while knowing the adab-the rules of good conduct-amounted to being at the top of the hierarchy. ${ }^{25}$ The

20 H. Dagan, The Realist Conception of Law, 21 Tel Aviv University Law Faculty Papers (2005), 1-66.

21 B. Leiter, Legal Realism, in D. Patterson (ed.), A Companion to Philosophy of Law and Legal Theory (1996), 261-79.

22 W. Twining, Talk about Realism, 60 New York University Law Review (1985), 329-84.

23 P. V. Kane, History of Dharmasastra (1962).

24 S. A. Kugle, Framed, Blamed and Renamed: The Recasting of Islamic Jurisprudence in Colonial South Asia, 35(2) Modern Asian Studies (2001), 257-313.

25 E. Giunchi, The Reinvention of Sharia under British Raj: In Search of Authenticity and Certainty, 69(4) The Journal of Asian Studies (2010), 1119-1142. 
Mughals followed the previous empire's pattern, by relying on the flexibility of the laws and much less on rigidifying.

The majority of the Indian population comprised of non-Muslims, thus making the tenets of Islamic law applicable to a minority alone. Yet, there were many similarities as there were differences between the Islamic and Hindu traditions. The biggest similarity between the Hindu and Islamic legal systems was of the importance they both gave to historical contexts and social considerations. Islamic law has been called a "fluctuating, elastic quid" 26 that accepted its internal contradictions and allowed the judge wide decision-making powers. Also, in settling disputes, more reliance was placed on customary practices than religious tenets found in written texts, on local arbiters than formal judicial methods. In making these judgments, more than sharia, the fiqh (or knowledge) was considered the text of reference by the qadi (or arbiter). The fiqh was the knowledge and understanding of the Sharia (through an interpretation (ijtihad) of the Quran) and Sunnah by Islamic jurists (also referred to as Ulamas). The fiqh texts provided the moral references for the judges. ${ }^{27}$ And the Fatawa-i-Alamgiri comprised of religious decrees from the Hanafi treatises that were compiled under the supervision of the then emperor, Aurangzeb, in a move to systematize and simplify legal precepts. ${ }^{28}$

\section{Islamic Law and its Transformations}

The Pre-Colonial period of Mohammadan law in India can be divided into two parts: the Sultanate and the Mughal periods. In the Sultanate period, the Sharia laws were applied more than during the latter period. The Mughals enforced the separateness between the Muslim and non-Muslim world regarding law application. Allowing their non-Muslim subjects to be governed by their customs and practices, the rulers had to confront the rather mature body of laws the Hindus relied on: the Dharmasastras.

There were different types of laws - the canon law (akhm-i-sharia) which related mainly to matters that were religious; criminal law (akham-i-jinayat, qanun-i-fawjdari) which comprised of criminal and tort matters; the king's regulations (qanun-i-shahi) dealing mostly with matters of land under feu-

26 E. Carusi, The Scientific Problem of Muslim Law (1919).

27 Similar to the concept of dharma, the fiqh provided the moral context of the Islamic tenets. Unlike in Hindu law, the Muslims did have codified laws to govern them, too.

28 Giunchi, supra note 25, 1122. 
dalism; customs and usages (qanun-i-urf), which was much like dharma; fatwas (or the use of precedents); and lastly, justice, equity and good conscience.

Customs and usages were as important to Muslim law as it was to the Hindu system. But unlike in Hindu law, where Dharma overrode any written laws, the Sharia was considered to prevail over whatever custom that conflicted with it. Yet, there were local customary practices that differed from community to community but were preserved despite the contradictions. A commonly cited example is that of the Fatimid law as opposed to the Hanafi law, where the deep-rooted differences were maintained. Sharia doctrine does, however, admit urf (literally, "what is known" about a thing) as a legal principle of subsidiary and supplementary value. ${ }^{29}$ Albeit in certain areas of legal practice, like that of contract, Sharia law was wholly abandoned for customary practices.

The use of precedents was not common in the Islamic system ${ }^{30}$ unlike under Common Law that the British introduced. But the concept of the fatwa bore resemblances to what we today call a precedent, in as much as it had the moral and legal authority owing to the scholars who issued them. Fatwas were preserved because they were considered to possess great persuasive value, even if not binding. Sharia doctrine did not recognize the notion of case-law, owing to being opposed to the idea of judicial precedent. The Islamic legal system, through its courts, applied the law and sought authority for each case through the texts alone. This, of course, led to instances where different qadis decided similar cases differently. ${ }^{31}$ Running counter to the modern insistence on uniformity and certainty, the Islamic law portrayed the characteristics that demonstrated the apparent indeterminacy of law; it debunked the myth around coherence of the law in what is often considered to be the superior colonial British transformations of the archaic Mohammadan systems. In general, the Islamic system during the rule of the Moghuls was a superior system of justice ${ }^{32}$ which the British rulers 'reformed' by introducing a system of judiciary, and principles of interpretation through the Charters of the 1600s, as the second part of this chapter will elucidate.

29 N. J. Coulson, Muslim Custom and Case-Law, 6 Die Welt des Islams (1959), 13-24.

30 A. A. Fyzee, Muhammadan Law in India (1941).

31 J. N. D. Anderson, Muslim Procedure and Evidence, 1(3) Journal of African Administration (1949), 15.

32 M. B. Ahmad, Administration of Justice in Medieval India (1941), 25. 
Criminal justice was administered in special courts which were called the fawdari courts, and civil justice was administered in the diwani courts. Criminal cases which otherwise invoked caste-related status, in the absence of castes in Islamic traditions, relied on possession of land. ${ }^{33}$

When it came to other forms of adjudicatory models, the concept of Siyasa, which was a type of procedural justice, was less a form of politics and more an ethos. Siyasa was the concept that ordered "law, state, and social interaction in Mughal South Asia." Even if the word Siyasa can be translated to mean 'politics' in Persian, Arabic and Urdu, it was the real dispute settlement method under the Moghuls comprising of negotiation, and any other means of resolving disputes by enabling interaction between the disputing parties. It was often cited as the ruler's "right to intervene in judicial affairs", while the famous Persian writer Ibn Muquaffa in the early Abbasid period called Siyasa the "necessary element in the very genesis of Sharia as a religious ideal". 34

\section{The Hierarchy of Courts and Judges in the Islamic Period (1526- 1707 AD)}

The Emperor (or the Khalif) was the highest judge. His court was considered to be the highest court of appeal, rather than of original proceedings. There was a Mir-Arz (loosely translatable to a bailiff or court-usher) who presented the people to the Emperor. The Quazi was the Chief Judge in the criminal matters, who was assisted by the Mufti who was expected to have an understanding of Islamic jurisprudence. There were local quazis for every city and large village. The Quazi-Ul-Quzat was the judicial officer on top of the hierarchy, made responsible for the management of judicial administration. There was also the Kotwal, or the police who was in charge of the administration of the fort, and a Mubtasib, who was in charge of censorship and public morality. It is thus clear that the Islamic system had in place a systematic method for carrying out both judicial and quasi-judicial functions.

With regard to the courts, there were different judicial agencies that worked independently of each other, yet simultaneously. Firstly, there were the religious courts: these were presided over by the kazis, and based on a reading of the Quran. Secondly, there were the secular courts: these were

33 F. B. Hakeem, From Sharia to Mens Rea: Legal Transition to the Raj, 22(2) International Journal of Comparative and Applied Criminal Justice (1998), 211-224.

34 A. al-Azmeh, Islams and Modernisms (1993). 
presided over by Faujdars and Kotwals. These courts also had Hindu priests who presided over for matters concerning Hindus; the village councils or the Panchayats fell within this category. Thirdly, there were the political courts, which decided matters of interest to the State, including criminal activity; they were presided over by Faujdars and Kotwals. The nature of offences had three categories, too: offenses against God, offenses against the State and offenses against individuals. The punishments were decided based on these categories and also the decision to compound the offense or not also relied on these categorizations. ${ }^{35}$

The Hindu and Muslim systems relied on informal settings for meting out justice, whilst equally possessing the hierarchical structures and means for a more formal judicial method. Appreciating the malleability of the law and religious principles they relied on, religious leaders and judges alike were granted wide-decision making powers, albeit within the contours of high ethical standards, showing evidence of a brand of pragmatism that was prevalent in those societies. The underlying principle of legal procedure was to rely on facts, rather than legal ploys, taking into account the social circumstances and history that were crucial to the context of the Indian societies. The criticisms against settling disputes and bringing about justice in the aforementioned ways were many, but the hindrances they caused the British in governing India were specific: firstly, the excessive roles played by the native (religious) leaders, who possessed the sole expertise in discerning the religious texts, in settling disputes within their respective communities; secondly, the social structural complexity that played a large role in determining the optimal solution while resolving disputes between parties from different social strata. Overcoming these hurdles required obliterating the role played by the religious leaders, best achieved through an introduction of laws that did not rely on the religious texts. At the same time, in order not to antagonize the local populations and their religious sentiments, the substantive content of their laws were best kept intact. Thus, the British relied on introducing procedural guarantees that could enable an intrusion into the Indian native legal system, before subsuming the entire legal system within their own. 


\section{A Turn to the Modern?: The Colonial Recalibration}

The pre-colonial legal system of India was multifaceted and could not lend itself easily to the Western liberal demands of homogeneity and uniformity. The peculiarities of the Indian system meant that the British needed to reduce the differences and homogenize the polity through a common lex fori ${ }^{36}$ to gain control of the unwieldy dominion. Therefore, the establishment of common legal codes was deemed pivotal to the British administration of justice in India, second only to the regulation of commerce. Even if unwritten laws, like that of the common law of England, do not support an easy transplantation, the Criminal Procedure Code, 1861, the Indian Evidence Act of 1872 and the Code of Civil Procedure of 1908 introduced specific branches of English procedural law which had no counterpart in any other legal system. ${ }^{37} \mathrm{I}$ argue in this section that contrary to the supposition that English laws and their phase of codification, from 1833 to 1882, brought about a heightened sense of fairness and equality through uniform procedural laws, the laws constructed racial difference and institutionalized inequality within the polity between the 'whites' and the 'blacks.'38 Thus the recalibration by the British raised the questions whether their purported attempts to 'modernize' signified an improvement and if so, for whom.

Scholarly writing on the legal history of India mostly allows the British credit for transforming what, as I described above, was a working, sometimes unsuccessfully, decentralized native system (that was deemed primitive) into a modern "unified" judicial system. The benefits accrued, as described by its plaudits, were of a simplified and systematized legal system and laws. ${ }^{39}$ One can discern various stages of the transformation of indigenous laws, but the gist of its change lay in the move from informal courts to government's courts, the curtailed applicability of indigenous law and the gradual transformation of the indigenous law in its application by the

36 K. Lipstein, The Reception of Western Law in India, 9 International Social Science Bulletin (1957), 87-91.

37 Ibid., 92; Lipstein stresses that irrespective of such introduction of British law, it was important to ask only whether such law was beneficial within the Indian setting; he equally insisted that the British adapted the laws to suit the needs at the local level.

38 E. Kolsky, Colonial Justice in British India: White Violence and the Rule of Law (2009), 78.

39 Galanter, supra note 3, 68. 
government's courts. ${ }^{40}$ But the colonial codification also posed a dilemma: the uniform system of law would equalize everyone and place the colonizer and the colonized on the same legal footing. Thus rather than creating what was portrayed as a universal and non-discriminating law, the codified laws of the British delivered something else entirely. ${ }^{41}$ In this section, I shall explore the mechanisms introduced by the British which, when juxtaposed with the historical descriptions of the Hindu and Muslim pre-colonial legal systems, shall illuminate some of the myths surrounding the advantages of the British coherent, uniform system of law.

\section{A. From Deference to Displacement: The Evolution of the Colonial Strategy}

One of the first notable changes executed during the colonial period in India was the Charter of 1661 which permitted The East India Company to exercise civil and criminal jurisdiction over those who resided within the premises of its factories, according to the laws of England. ${ }^{42}$ The Company's early legal system thrived on its demarcation between the Company's officials and the Indian natives, while reimagining India as English territory and treating the Indians as aliens on their own land. Yet, the Company had not yet begun reimagining the entire polity as their own in the seventeenth century. The local laws and practices outside of the boundaries of the Company continued to maintain its relevance and applicability towards the natives.

In the eighteenth century, the Company extended its legal reach by establishing a system of laws and court systems that ran parallel to the existing Indian ones. The Hastings Plan of 1772, named after the first Governor-General of India: Warren Hastings, established a hierarchy of civil and criminal courts, which were given the task of applying indigenous laws in matters that related to inheritance, marriage, caste and other religious usages. ${ }^{43}$ Hastings had created a binary category of Hindus (referred to as Gentoo) and Muslims (or Mohammadans); this binarism, even if partially reflective of the largest religious communities, did not reflect the diversity within the religions. As the first section of this chapter recounted, the Hin-

40 Galanter, supra note 3.

41 See Kolsky, supra note 38, 72.

42 See Kolsky, supra note 38, 30.

43 M. Anderson, Islamic Law and the Colonial Encounter in British India, in D. Arnold and P. Robb (eds.), Institutions and Ideologies: A SOAS South Asia Reader (1993). 
du and Mohammadan systems were not separately homogenous either; they each had their own set of nuances, whether desirable or not. "Not only did it [the Hastings Plan] fail to acknowledge the distinction between Shias and Sunnis and the differences among the schools within each; it also failed to address adequately the practices and beliefs of the many groups that adopted an eclectic approach to Islam and various forms of Hinduism." 44 The terms Hindu and Muslim, as Anderson very appropriately noted, were imbued with the Procrustean quality that forms the basis of my assessment in this section. Albeit uncaring of the complexities of the Hindu and Mohammadan systems respectively, the 1772 Regulations continued to show an apparent deference to the local practices. It laid down the basis for arbitration between Indians: officers would apply the local laws of Hindus and Muslims to matters of inheritance, marriage, caste and religious institutions, while the English officers would directly supervise the settlement of disputes by enforcing procedural regularities. ${ }^{45}$

Their inheritance and succession to lands, rents, goods, and all matters of contract and dealing between party and party, shall be determined in the case of Mahomedans [Muslims] by the laws and usages of the Mahomedans, and in the case of Gentoos [Hindus] by the laws and usages of Gentoos, and where one only of the parties shall be a Mahomedan or Gentoo, by the laws and usages of the defendant. ${ }^{46}$

The subtleties of the regulations turned the position given to the British Company officials into an invisible fulcrum around which all the indigenous laws revolved in actuality. Under the pretense of deferring to the Hin$\mathrm{du}$ and Muslim institutions on the one hand, on the other hand the British slowly began reordering both the legal and political structures. For example, to enable the British magistrates to interfere with the local courts in order to "supply the deficiencies and correct the irregularities" 47 in the Muslim laws of sentencing, the British relied on siyasa, which was the right of (Mughal) rulers to circumvent the "formal procedures of Islamic fiqh" 48 to allow the British officers to interfere. The reliance on the local customs and rules was a pall behind which the colonizers found their advantages. Structurally, there were less subtle initiatives carried out-to remove the In-

44 Ibid., 11.

45 Kugle, supra note 24, 262.

46 W. Hastings, Mufassal Regulations (1772) (formally enacted as the Regulations of 1780).

47 Kugle, supra note 24, 264.

48 Ibid. 
dian officers and set up a governmental judiciary that was separate from the native population; Governor General Cornwallis kept the Indian officers in minor roles alone, while also demoting people of mixed race. These changes slowly allowed the British to occupy positions of superiority from mere supervisory roles.

When it came to deference to local norms, there is evidence to show that the British did preserve the local laws and customs at first, but both the Islamic and Hindu law transformed into Anglo-Hindu law and AngloMohammadan law. With the unwillingness to publish texts, procure translations or to record the local customs, there was an inconspicuous indifference to the local laws. By severing parts of the Hindu and Muslim laws from the large bodies to which they belonged, the British removed the contextual meanings of many of their laws. Some Hindu rules were "silently abolished" through this method of distortion. ${ }^{49}$

\section{B. A Procedural Alteration of Substantive Laws}

One of the major measures implemented by the British was to engraft into the native legal system English procedural laws. The Anglicization of procedural laws was not inadvertent; it rested on strong theoretical grounds of why procedural, rather than substantive, laws were reformed. The first justification given by the British was 'good government', through a fair administration of justice. As Jorg Fisch describes, "while the Europeans administered or controlled indigenous material, they were bound to introduce, whether intentionally or unintentionally, parts of their own procedure, all the more so as European interference was justified with the lack of good government in the pre-European system". 50 The second justification was the assumption that rules of evidence and other rules of procedure were of a universal nature, less culturally sensitive than substantive laws. ${ }^{51}$ Thus the British presumed a "facile translatability" 52 of procedural fields. And thirdly, a procedural similarity across the Empire allowed the British mobility

49 Derrett, Critique of Modern Hindu Law, supra note 18, 40.

$50 \mathrm{~J}$. Fisch, Law as a Means to an End: Some Remarks on the Function of European and Non-European Law in the Process of European Expansion, in W. J. Mommsen and J. A. De Moor (eds.), European Expansion and Law: The Encounter of European and Indigenous Law in 19th- and 20thCentury Africa and Asia (1992).

51 B. Blum, Evidence Rules of Colonial Difference: Identity, Legitimacy and Power in the Law of Mandate Palestine, 1917-1939 (2011).

52 Ibid. 
despite the variance in the substantive laws. ${ }^{53}$ Using British procedural methods, the substantive law was surreptitiously altered. ${ }^{54}$ There were situations in which a bringing about of a seemingly necessary procedural rule markedly altered the substantive rights. ${ }^{55}$ Most importantly, the colonial courts introduced new legal mechanisms - of bureaucratic procedure and methods of inquiry - that were widely divergent from the pre-colonial practices.

Through procedural alterations, one of the most significant British innovations was brought about-of using documentation in matters of law and evidence. ${ }^{56}$ As demonstrated in the previous sections, the Hindu and Muslim legal processes relied largely on oral testimonies and the probity of witnesses. ${ }^{57}$ Thus, because laws such as the Al-Hidaya under Islamic law or Responsas in the Hindu legal system made no provision for documentary evidence (governing the admissibility of oral testimony alone, as under the Gautama Sutras, for example), this maneuver by the British resulted in a shift that obscured the natives. There was, therefore, a slow reduction of access to legal institutions for the mostly illiterate population. The Criminal

53 A. Likhovski, Law and Identity in Mandate Palestine (2006), 55.

54 D. M. Derrett, The Administration of Hindu Law by the British, 4 Comparative Studies in Society and History (1961), 10-52.

55 For example, in the famous Privy Council case of Her Highness Ruckmaboye v. Lulloobhoy Mottichund, by dealing with the procedural concept of Statute of Limitations, the court curtailed the assertion of the rights available. By emphasizing on what the Statute of Limitation entailed, the British set an important precedent that was followed for years to come in the Indian Courts. For example Khondkar Mahomed Saleh v. Chandra Kumar Mukerji A.I.R. 1930 Cal. 34; Baijnath v. Doolarey Hajjam A.I.R. 1928 All. 708; and Ram Karan v. Ram Das A.I.R. 1931 All. 635 at p. 639 lay down that law of limitation is procedural law. The Privy Council held in Shahid Ganj Mosque v. Shiromani Gurdwara Prabandhak Committee A.I.R. 1940 P.C. 116 that the limitation for a suit is governed not by the law existing when the cause of action accrued but by the law existing at the time of the institution of the suit because limitation is "a matter of procedure" (per Sir George Rankin at p. 121). "The propositions that procedural law is retrospective and that law of limitation is procedural law gave rise to the proposition that law of limitation starts applying at once in the absence of words to the contrary, and a proceeding is governed by the law of limitation in force at the time of its institution and not by the previous law of limitation that might have existed at the time of accrual of the cause of action for it." Khem Chand Keshrimal vs. Commissioner Of Sales Tax, 196719 STC 71 All, para 14.

56 R. S. Smith, Rule-by-records and Rule-by-reports: Complementary Aspects of the British Imperial Rule of Law, 19 Contributions to Indian Sociology (1985).

57 Anderson, Islamic Law and the Colonial Encounter in British India, supra note 43, 17. 
Procedure Code of 1861 and the Indian Evidence Act of 1872 brought about the English procedural law and evidence into the Indian legal system in a form they imagined was systematic and uniformly applicable to both, Hindu and Muslim legal systems.

Although the courts adopted a British model of procedure and adjudication, The Hastings Plan of 1772 provided for the maulvis and pandits to advise the court on matters related to Islamic and Hindu laws respectively. Except, the transformations of the laws into Anglo-Mohammadan and Anglo-Hindu laws had turned them into versions very unlike the original. These religious experts were attached to district and appeal courts on matters that the British considered religious, in order to help them retrieve the relevant norms contained in religious texts. ${ }^{58}$ Yet, the local advisors were deprived of their traditional roles; the English judges relied on a translator to ask for the doctrinal positions; these questions were often asked in an abstract manner, without any contextual details, in order to receive an equally abstract response. This enabled a wide enough margin for interpretation that suited the British needs. The British found their reliance on the religious experts disempowering, therefore the need to eradicate them from the judicial process was imperative. Thus, deciding to create what Giunchi calls a "direct relationship with the source texts", starting in the second half of the eighteenth century, the British engaged in translations extensively in order to formulate clearer and less varied codes. The contextual consistencies of the local laws, like the figh, which brought about "the contextual consistency of the qadi, was thus transformed into formal and substantial consistency through precise formulas, procedures and concepts that the British judges could understand." ${ }^{99}$ Language was power and translations were the key to permeate the indigenous systems in India. Stating Hindu or Muslim rules in English distorted their meaning, but touting it as an inevitable measure, the British desired for their own judges to apply the indigenous laws directly. ${ }^{60}$ Largely leading to an obsolescence of customs, the chasm between customary law and court law was reduced considerably. With the help of Warren Hastings who was an expert in Urdu and Persian, the British began translating the Fatwas and the Hedaya (a commentary on Islamic laws) from Arabic to Persian and then from Persian to English. ${ }^{61}$ Similarly, the Hindu text, Dharmasastra, was translated

58 Giunchi, supra note 25, 1126.

59 Ibid., 1127.

60 Anderson, Islamic Law and the Colonial Encounter in British India, supra note 43, 13.

61 Giunchi, supra note 25, 1127. 
into Persian from Sanskrit and then to English by an official from the East India Company, Nathaniel Brassey Halhead. This text was re-titled A Code of Gentoo Laws. As Giunchi points out in her critical appraisal of how the British reinvented the local laws, there was an Orientalist assumption underlying most of the changes made: "that the religious texts were internally inconsistent", ${ }^{2}$ whilst in reality they fueled the imperialist mission of colonizing the laws.

The nineteenth century saw more concerted efforts on the part of the British to enable their 'civilizing mission' through procedural mechanisms. The Code of Criminal Procedure (1861) provides a pertinent example of what the imperialist mission stood for in reality: a subversion of legal equality and the legal construction of racial difference. Complaining that they would be subject to the "barbarous and proselytizing law unsuited to Christian or civilized men", ${ }^{63}$ the 'uniform' code stipulated that the juries for the Europeans would comprise of only Europeans, while inapplicable to the Indians; furthermore, the trials for the Europeans were granted at the higher courts (also called Presidency trials), while the Indians were granted access only to the local courts. The schedules for punishment were equally differentiated based on race, leading to a legal inequality the Company officials claimed was a pre-existing characteristic of "a caste-saturated and backward place like India". 64

Apart from the procedure codes for criminal acts, many Jurisdiction Bills were also passed that explicitly maintained the racial differences under the law. British subjects were exempted from the mofussil courts. Indian elites, like Rajah Kally Krishna and Ram Gopal Ghose, protested that the practical effects of the British system placed the Englishmen above the law. From the use of the English language that was unknown to the millions of Indians, to being governed by laws that were beyond their comprehension, the legal system internalized the belief that the Englishman was a superior being who could not be subjected to the same laws which gov-

62 Ibid., 1128.

63 "Memorial of the undersigned persons of English, Scottish and Irish birth or descent, inhabitants of the territories of the Crown of India at present under the Government of the East India Company," 22 January 1850, Legislative Consultations of 10 May 1850, No. 44, British Library, IOR, P/207/60.

64 Judicial dispatch from Court of Directors, No. 6, 30 September 1835, Legislative Proceedings, 10 October 1836, Nos. 20-21; See also Kolsky, supra note 38, 78. 
erned the barbarians. 65 "Equality for all" was indeed a "miserable sham" 66 if it purported that the Europeans and the Indians were standing on equal footing, said Calcutta Supreme Court Justice Arthur Buller.

\section{The Myth of the Procrustean Bed of Colonial Laws}

The notion that the European legal mechanisms were well-suited to the Indian subcontinent was based on a concerted attempt to transform the polity to one that the British could manage. The judicial systems formed the crux of the British imperial system, and within that a procedural guarantee that demonstrated their desire to bring about good governance and a fair administration of justice was a more plausible argument to make to the local population, while resolutely strategizing ways to maintain the inequality. While on the one hand suggesting the primitiveness of the native laws and on the other hand creating a 'uniform' system that they could exempt themselves from, the myth of modernizing of the Indian legal system became a self-perpetuating prophesy that exists even today.

In this paper, through a demonstration of what the Hindu and Islamic laws were in pre-colonial India, it becomes clear that there was a legal system that functioned to serve the needs of its diverse local population, with the members of the local community retaining personhood. The idea of a uniform code was unfathomable to a populace that thrived on their cultural distinctiveness, moreover because it moved the space of legal action away from the population it served. Thus leaving only personal laws outside their control, the British imposed their abstract notions of procedural, and later substantive, guarantees in a way that deemed it predictable and universal. Such predictability came with the guarantee that all would enjoy the same rights, equally and impartially under the law, except that the British would be above the law. The promise of equality brought about two further promises, as Cohn writes: one, of Britain working to maintain the diversity in the Indian society, of its religion and culture, and second, of Britain ameliorating India's social and material well-being. The contradiction lay in the fact that in order to fulfil the first, the colonizers needed to protect India's traditional feudal society, whilst in order to fulfil the sec-

65 R. G. Ghose, Remarks on the "Black Acts", 412-413, 420.

66 Sir Arthur Buller's speech of 09 March 1857, National Archives of India, Legislative Council Proceedings (1857), Vol III. 
ond promise, Britain felt a modernization of the society was essential through an inevitable destruction of the feudal and religious society. 